\title{
Decreased vitamin D levels in children with primary mono-symptomatic nocturnal enuresis
}

\author{
Farida M. El-Baz , Marian G. R. Abdelsayed ${ }^{1}$, Aziza S. Abdel-Hafeez ${ }^{2}$ and Reham I. Abdelmageed ${ }^{1 *}$ (1)
}

\begin{abstract}
Background: Nocturnal enuresis (NE) is a common voiding problem in pediatric populations. Relatively, few studies have investigated the 25-Hydroxyvitamin D and NE associations in children, which may open up a new research area on the effect of vitamin $D$ as nutritional therapy in the treatment of NE. The aim of this study was to determine the level of 25-hydroxyl vitamin D among children and adolescents with nocturnal enuresis in comparison to nonenuretic Egyptian children.

Results: Fifty children (24 females, 26 males) who presented with primary mono-symptomatic nocturnal enuresis (PMNE) and 50 healthy children (23 females, 27 males) were recruited in this study. A structured questionnaire focusing on demographic, socioeconomic, and frequency of bed-wetting were collected, and vitamin D serum levels were assessed in all children. In the NE group, the mean value of serum vitamin D levels was lower than the control $(19.0 \pm 6.5$ versus $23.89 \pm 4.19 ; P<0.0001)$. Serum 25 -hydroxyvitamin D levels were abnormal $(<20 \mathrm{ng} / \mathrm{mL})$ in $46 \%$ of children with NE and $16 \%$ of controls $(P<0.001)$. The higher bed-wetting frequencies were associated with lower levels of 25(OH) D (Every night: 7.0 $\pm 1.4,3-5$ time/week: 11.2 $\pm 1.7,1-3$ times/week: 17.6 $\pm 3.7,<2$ times/week: $22.4 \pm 2.9$, Once/6 month: $24.1 \pm 4.3(\mathrm{ng} / \mathrm{ml}), P<0.001)$.

Conclusion: A difference in serum 25-hydroxyvitamin $D$ levels was found between the two study groups. There is a need for more studies to explain vitamin D deficiency in larger series so that this test can be used in regular enuretic child investigations.
\end{abstract}

Keywords: Vitamin D, Nocturnal enuresis, Children, Primary mono-symptomatic

\section{Background}

Enuresis is a common pediatric condition that can cause psychological distress in children and their families. Enuresis refers to discrete urinary incontinence episodes in children of 5 years age and older who are asleep [1]. Enuresis, while the pathogenesis and evaluation of the two types overlap, is divided into mono-symptomatic and non-mono-symptomatic forms [2]. Enuresis without any other urological symptoms is known as

\footnotetext{
*Correspondence: rehamibrahim@med.asu.edu.eg

${ }^{1}$ Pediatrics Department, Faculty of Medicine, Ain Shams University, Cairo,

Egypt

Full list of author information is available at the end of the article
}

mono-symptomatic NE. The term non-mono-symptomatic is for all other children who do not meet these criteria [1]. In children aged 5 years and above, the incidence of NE appears to be around 20 percent with a male predominance [3].

The prevalence of NE in Egyptian children was 15.5\% in a study conducted in Benha. [4]. Data on recent studies indicate that $16.5 \%$ of Children suffered from NE Minia City, Egypt [5].

Nocturnal polyuria, decreased bladder capacity, detrusor over activity, global maturation delay, related sleep arousal disturbances, and genetics are the common underlying pathophysiology of NE. NE, mostly, is 
a multifactorial disorder caused by a mixture of these etiologies [6].

25-hydroxyvitamin $\mathrm{D}$ is a fat-soluble vitamin with several functions and target organs. The influence of many genes can be affected by vitamin $\mathrm{D}$ and its receptor (VDR) following binding. VDR expression is usually in the bone cells, kidney, skin cells, and other cells [7]. Moreover, accumulating epidemiological and laboratory evidence documented that levels of 25-hydroxyvitamin D are closely related to the occurrence of many chronic conditions [8]. Although a little information about the effect of vitamin D deficiency and the risk of bed-wetting is known, an inverse association between $25(\mathrm{OH}) \mathrm{D}$ and $\mathrm{NE}$ in children was reported in a Chinese study for the first time [9]. They proposed that there is some link between 25-hydroxyvitamin D and NE based on the impact of 25-hydroxy vitamin D on different physiological mechanisms and suboptimal 25-hydroxyvitamin D concentrations may be the leading cause of excessive urine production [9]. As far as we know, no study has been conducted in Egypt in this respect. Thus, this study aimed to determine the level of vitamin D among Egyptian children with NE.

\section{Methods}

One hundred children and adolescents in the age group between five and 16 years old from December 2019 to May 2020 were recruited in this study. Of the 100 children under study, 50 children with Primary mono-symptomatic NE were consecutively selected from psychiatry Clinic, Pediatrics Hospital, as the case group in accordance to the Standardization Committee of the International Children's Continence Society [1], and 50 age and sex matched healthy children without enuresis in the control group. The inclusion criteria is two or more enuretic episodes a week for at least three consecutive months in children aged 5 to 16; while the exclusion criteria included: supplemental vitamin $\mathrm{D}$ intake $>400 \mathrm{IU} / \mathrm{d}$, daytime wetting, infection of the urinary tract during the past three months, polyuric diseases, abnormal urine test, abnormality of the urinary tract, history of genitourinary abnormality, associated neurological abnormalities, associated chronic illness and any significant drug intake.

The required sample size was calculated using the Epitools program setting to detect the alpha error at $5 \%$ and power at $80 \%$.

Ethical approval was obtained from the Research Ethics Committee at the Faculty of Medicine, (Ethical Committee No. FMASU R86 /2020).

\section{Questionnaires}

Using a structured questionnaire, demographic data were collected, and Socioeconomic Standard was assessed using the new version scale of the Arabic validated Socioeconomic Status Scale for research study in Egypt [10].

\section{5-hydroxyvitamin $D$ assessment}

The Serum samples of collected blood from all children were separated, centrifuged, and preserved at $-20{ }^{\circ} \mathrm{C}$ until the laboratory assessments. We used the Cal biotech Vitamin D Kit, a solid phase enzyme-linked immunoassay (ELISA), to detect serum vitamin D levels. The cut-off value of 25 -hydroxyvitamin $D$ deficiency was $<20 \mathrm{ng} / \mathrm{ml}$ [11].

\section{Statistical analysis}

The collected data were revised, coded, and introduced using IBM SPSS Statistics version 23. Continuous variables were represented by the mean and standard deviation, while categorical variables were represented by percentages. Comparisons between the groups were made using an independent $t$ test for continuous variables and a chi-squared test for categorical variables. The value of serum vitamin $\mathrm{D}$ level for discrimination between cases and controls was examined using receiveroperating characteristic (ROC) curve analysis. The Kruskal-Wallis test was used to determine the relationship between bed-wetting frequencies and $25(\mathrm{OH}) \mathrm{D}$ levels. P value of less than 0.05 was considered statistically significant.

\section{Results}

Of 100 children/adolescents included in the study, the mean age in the $\mathrm{NE}$ and control groups was $9.24 \pm 2.54$ and $9.20 \pm 2.51$ years, respectively. No significant differences were observed in both study groups in gender, height, weight, and birth order. In addition, no differences were found in the educational levels of the parents, per-capita income, and socioeconomic status between the two groups (Table 1).

The mean value of serum vitamin D was statistically significantly lower in the NE group compared to controls $(19.0 \pm 6.5$ versus $23.89 \pm 4.19 ; P<0.0001), 46.0 \%$ of the NE group had vitamin D deficiency compared to (16.0\%) in controls $(P<0.001$; Table 2$)$. Receiver operating characteristics (ROC) curve was used to define the best cut-off value of vitamin $\mathrm{D}$ that was $\leq 19 \mathrm{ng} / \mathrm{ml}$, with a sensitivity of $46 \% \%$, a specificity of $84 \%$, the positive predictive value of $74.2 \%$, negative predictive value of $60.9 \%$, and area under the curve (AUC) of $0.616, P<0.046$; Fig. 1). The lower $25(\mathrm{OH}) \mathrm{D}$ concentrations were associated with higher frequencies of bed-wetting (Every night: 
Table 1 Baseline characteristics of the study population ( $N=100)$

\begin{tabular}{|c|c|c|c|c|}
\hline Characteristics & Nocturnal enuresis $(n=50)$ & Control $(n=50)$ & Test value & $P$ value* \\
\hline \multicolumn{5}{|l|}{ Age (years) } \\
\hline Mean \pm SD & $9.24 \pm 2.54$ & $9.20 \pm 2.51$ & $0.351^{\mathrm{a}}$ & 0.726 \\
\hline \multicolumn{5}{|l|}{ Weight (kg) } \\
\hline Mean \pm SD & $24.38 \pm 4.86$ & $25.08 \pm 5.11$ & $0.702^{\mathrm{a}}$ & 0.484 \\
\hline \multicolumn{5}{|l|}{ Height (cm) } \\
\hline Mean $\pm S D$ & $122.92 \pm 12.23$ & $125.40 \pm 12.37$ & $1.008^{\mathrm{a}}$ & 0.316 \\
\hline \multicolumn{5}{|l|}{ Gender } \\
\hline Male & $26(52.0 \%)$ & $27(54.0 \%)$ & $0.040^{b}$ & 0.841 \\
\hline Female & $24(48.0 \%)$ & $23(46.0 \%)$ & & \\
\hline \multicolumn{5}{|l|}{ Gestational age } \\
\hline Full term & $43(86.0 \%)$ & $33(66.0 \%)$ & $5.482^{b}$ & 0.019 \\
\hline Pre term & $7(14.0 \%)$ & $17(34.0 \%)$ & & \\
\hline \multicolumn{5}{|l|}{ Birth order } \\
\hline 1st & $13(26 \%)$ & $8(16 \%)$ & $1.598^{b}$ & 0.659 \\
\hline 2nd & $15(30 \%)$ & $16(32 \%)$ & & \\
\hline $3 r d$ & $15(30 \%)$ & $17(34 \%)$ & & \\
\hline 4th & $7(14 \%)$ & $9(18 \%)$ & & \\
\hline \multicolumn{5}{|l|}{ Mother's education } \\
\hline Illiterate/read and write & $5(10.0 \%)$ & $6(12.0 \%)$ & $7.15^{b}$ & 0.30 \\
\hline Literate certificate & $4(8.0 \%)$ & $3(6.0 \%)$ & & \\
\hline Primary & $13(26.0 \%)$ & $4(8.0 \%)$ & & \\
\hline Preparatory & $9(18.0 \%)$ & $13(26.0 \%)$ & & \\
\hline Secondary & $13(26.0 \%)$ & $14(28.0 \%)$ & & \\
\hline University & $2(4.0 \%)$ & $5(10.0 \%)$ & & \\
\hline Postgraduate & $4(8.0 \%)$ & $5(10.0 \%)$ & & \\
\hline \multicolumn{5}{|l|}{ Father's education } \\
\hline Illiterate/read and write & $0(0.0 \%)$ & $0(0.0 \%)$ & $8.471^{b}$ & 0.132 \\
\hline Literate certificate & $0(0.0 \%)$ & $1(2.0 \%)$ & & \\
\hline Primary & $2(4.0 \%)$ & $3(6.0 \%)$ & & \\
\hline Preparatory & $16(32.0 \%)$ & $8(16.0 \%)$ & & \\
\hline Secondary & $22(44.0 \%)$ & $19(38.0 \%)$ & & \\
\hline University & $10(20.0 \%)$ & $16(32.0 \%)$ & & \\
\hline Postgraduate & $0(0.0 \%)$ & $3(6.0 \%)$ & & \\
\hline \multicolumn{5}{|l|}{ Mother's work } \\
\hline Yes & $12(24.0 \%)$ & $15(30.0 \%)$ & $0.456^{b}$ & 0.49 \\
\hline No & $38(76.0 \%)$ & $35(70.0 \%)$ & & \\
\hline \multicolumn{5}{|l|}{ Father's work } \\
\hline Yes & $42(84.0 \%)$ & $43(86.0 \%)$ & $0.078^{b}$ & 0.779 \\
\hline No & $8(16.0 \%)$ & $7(14.0 \%)$ & & \\
\hline \multicolumn{5}{|l|}{ Per-capita income } \\
\hline Not enough + loan not repaid & $4(8.0 \%)$ & $3(6.0 \%)$ & $4.035^{b}$ & 0.401 \\
\hline Not enough + big loan & $8(16.0 \%)$ & $5(10.0 \%)$ & & \\
\hline Not enough + small loan & $18(36.0 \%)$ & $12(24.0 \%)$ & & \\
\hline Enough only & $14(28.0 \%)$ & $21(42.0 \%)$ & & \\
\hline Enough and saving & $6(12.0 \%)$ & $9(18.0 \%)$ & & \\
\hline \multicolumn{5}{|l|}{ Crowding index } \\
\hline$>4$ & $37(74.0 \%)$ & 39 (78.0\%) & $0.219^{b}$ & 0.640 \\
\hline$(2-4)$ & $13(26.0 \%)$ & $11(22.0 \%)$ & & \\
\hline$<2$ & $0(0.0 \%)$ & $0(0.0 \%)$ & & \\
\hline
\end{tabular}


Table 1 (continued)

\begin{tabular}{|c|c|c|c|c|}
\hline Characteristics & Nocturnal enuresis $(n=50)$ & Control $(n=50)$ & Test value & $P$ value* \\
\hline \multicolumn{5}{|c|}{ Total socioeconomic status } \\
\hline High & $14(28 \%)$ & $16(32 \%)$ & $0.368^{b}$ & 0.83 \\
\hline Middle & $25(50 \%)$ & $22(44 \%)$ & & \\
\hline Low & $11(22 \%)$ & $12(24 \%)$ & & \\
\hline
\end{tabular}

SD, standard deviation; \%, percentage

${ }^{*} P$ value $<0.05$ : Significant

${ }^{a}$ Independent t test

${ }^{\mathrm{b}}$ Chi-square test

Table 2 Comparison between the two studied groups according to vitamin D

\begin{tabular}{lllll}
\hline Vitamin D & $\begin{array}{l}\text { Nocturnal } \\
\text { enuresis } \\
(\boldsymbol{n}=\mathbf{5 0})\end{array}$ & Control $(\boldsymbol{n}=\mathbf{5 0})$ & Test of sig & $\boldsymbol{P}$ \\
\hline$<20 \mathrm{ng} / \mathrm{ml}$ & $23(46.0 \%)$ & $8(16.0 \%)$ & $x^{2}=10.519$ & 0.001 \\
$>20-\mathrm{ng} / \mathrm{ml}$ & $27(54.0 \%)$ & $42(84.0 \%)$ & & \\
Mean \pm SD & $19.0 \pm 6.5$ & $23.89 \pm 4.19$ & $4.471^{*}$ & 0.0001 \\
\hline
\end{tabular}

$x^{2}$, Chi square test

*Independent $t$ test. Statistically significant at $P \leq 0.05$

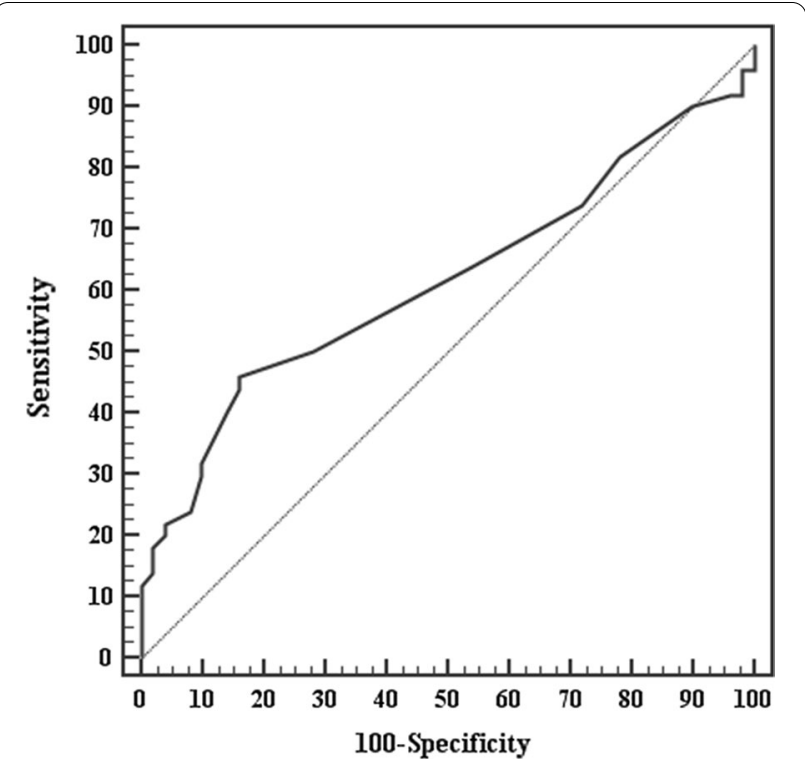

Fig. 1 Receiver operating characteristics (ROC) curve. Receiver operating characteristics (ROC) curve was used to define the best cut-off value of vitamin D that was $\leq 19 \mathrm{ng} / \mathrm{ml}$, with sensitivity of $46 \%$ $\%$, specificity of $84 \%$, positive predictive value of $74.2 \%$ and negative predictive value of $60.9 \%$, with an area under the curve (AUC) of $0.616, P<0.046$
$7.0 \pm 1.4,3-5$ time/week: $11.2 \pm 1.7,1-3$ times/week: $17.6 \pm 3.7,<2$ times/week: $22.4 \pm 2.9$, Once/6 month: $24.1 \pm 4.3$ (ng/ml), $(P<0.001$; Table 3, Fig. 2$)$.

\section{Discussion}

Nocturnal enuresis, better known as bed-wetting, happens when at night, a sleeping child is unable to retain its urine. It is a common childhood problem with little more male predominance. To children, parents, and health care providers, this problem can be stressful. The mean age of the enuretic children was $9.24 \pm 2.54$ years. Several studies have shown that the NE level decreases as age increases [12]. According to Alhifthy et al. [13] the prevalence of NE was $63 \%$ at the age of $6-7$ years and $4.5 \%$ at the age of $10-12$ years old that is consistent with previous reports $[5,14]$. In this study, the order of birth was not significantly different between both groups, and this agrees with a Turkish study that reported no association between birth order and the prevalence of NE [15]. However, Kamal et al. reported that birth order had a significant effect on the prevalence of enuresis as it occurs more frequently in the second child than in the first or third child [5]. The present study showed no differences in socioeconomic status between both groups. Similarly, Dolgun et al. [16] found that socioeconomic development did not affect the prevalence of enuresis. However, several studies mentioned that low socioeconomic status is a consistent risk factor for the incidence of wetting problems $[3,5,17]$. Although NE is a common childhood problem, the mechanism of this condition remains unclear. Also, several studies highlighted the impact of deficiency of some vitamins in nocturnal enuresis etiopathogenesis. Enuretic children, for example, have lower levels of serum vitamin B12 and folate than their non-enuretic counterparts [18, 19].

The present study showed that the NE group had a significantly lower mean vitamin $\mathrm{D}$ level than controls (19.0 \pm 6.5 versus $23.89 \pm 4.19$ ). Moreover, $84 \%$ of controls had optimal vitamin D status, whereas in NE, $46 \%$ 
Table 3 Relation between frequency bed-wetting with vitamin D

\begin{tabular}{|c|c|c|c|c|c|c|c|}
\hline \multirow[t]{2}{*}{ Vitamin D } & \multicolumn{5}{|c|}{ Frequency bed wetting } & \multirow[t]{2}{*}{ Test of sig } & \multirow[t]{2}{*}{$P$ value } \\
\hline & $\begin{array}{l}\text { Every night } \\
(n=6)\end{array}$ & $\begin{array}{l}3-5 / w k \\
(n=6)\end{array}$ & $\begin{array}{l}1-3 / \text { wk } \\
(n=10)\end{array}$ & $\begin{array}{l}<2 / w k \\
(n=17)\end{array}$ & $\begin{array}{l}\text { Once/6 months } \\
(n=11)\end{array}$ & & \\
\hline$<20 \mathrm{ng} / \mathrm{ml}$ & $6(100.0 \%)$ & $6(100.0 \%)$ & $7(70.0 \%)$ & $3(17.6 \%)$ & $2(18.2 \%)$ & $x^{2}=25.13$ & $<0.001$ \\
\hline$>20-\mathrm{ng} / \mathrm{ml}$ & $0(0.0 \%)$ & $0(0.0 \%)$ & $3(30.0 \%)$ & $14(82.4 \%)$ & $9(81.8 \%)$ & & \\
\hline Mean \pm SD & $7.0 \pm 1.4$ & $11.2 \pm 1.7$ & $17.6 \pm 3.7$ & $22.4 \pm 2.9$ & $24.1 \pm 4.3$ & $H=28.014$ & $<0.001$ \\
\hline
\end{tabular}

$X^{2}$, Chi-square test; $\mathrm{H}, \mathrm{H}$ for Kruskal-Wallis test; Pairwise comparison bet. each 2 groups was done using Post Hoc Test (Dunn's for multiple comparisons test)

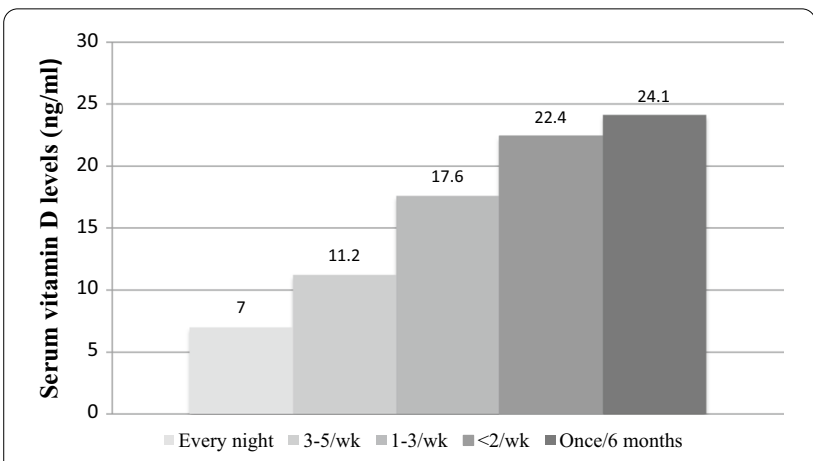

Fig. 2 The frequency of bed-wetting according to $25(\mathrm{OH}) \mathrm{D}$ concentrations. The lower mean $25(\mathrm{OH}) \mathrm{D}$ concentrations were associated with higher frequencies of bed wetting (Every night: 7.0 \pm 1.4, 3-5 time/week: 11.2 $\pm 1.7,1-3$ times/week: 17.6, < 2times/ week: $22.4 \pm 2.9$, Once/6 month: $24.1 \pm 4.3(\mathrm{ng} / \mathrm{ml}), P<0.001$

had vitamin $\mathrm{D}$ deficiency. In the present study, lower $25(\mathrm{OH}) \mathrm{D}$ concentrations were associated with higher frequencies of bed-wetting.

To the best of our knowledge, Li et al. reported for the first time in a study conducted on 247 Chinese children that one-third of children who suffering from NE had vitamin $\mathrm{D}$ deficiency [9]. They revealed that an increased frequency of bed-wetting was related to low $25(\mathrm{OH}) \mathrm{D}$ levels. Furthermore, as the level of $25(\mathrm{OH}) \mathrm{D}$ decreases, the severity of NE rises. They outlined their findings by analyzing the effect of low levels of vitamin $\mathrm{D}$ on the architecture of sleep which is considered as one of the main mechanisms of NE. Some studies have demonstrated that children who suffered from enuresis have disrupted sleep with several intermittent arousals that result in fragmentation of sleep and poor quality of sleep [20]. Some previous studies have shown an association between sleep disturbance and NE [21], which confirmed with Nevéus' report stating that the sleep problem is closely related to the pathophysiology of nocturnal enuresis [22]. Children suffered from NE may have a high threshold of cortical arousability, so they will not wake up when the bladder reaches its maximum capacity. Several studies have demonstrated that vitamin D (VDR) receptors are expressed in brain regions that control sleep regulation, such as the hypothalamus $[23,24]$. The higher vitamin D status was negatively linked to the risk of sleep disorders in these studies. Suboptimal vitamin D levels have been reported to correlate with poorer quality of sleep [25]. Interestingly, emerging evidence suggests that vitamin D may play an immunomodulatory function by changing immune regulation, reducing inflammatory substances release that control sleep, like tumor necrosis factor alpha, prostaglandin D2, and cytokine [26, 27]. The vitamin D deficiency-related spectrum of disease is likely to include immune dysregulation diseases that may be manifested by excessive sleepiness throughout the day induced by inflammatory cascade components. Thus, it is mechanistically possible that suboptimal vitamin D levels through modulation of immune-regulating substances will contribute to impaired sleep quality [28]. Together, these findings support the theory that vitamin D deficiency through its effect on sleep quality may lead to an increased risk of bed-wetting.

The function of vitamin $\mathrm{D}$ in the regulation of water channels was investigated in animal studies of mice kidneys. Polyuria has been shown to develop in VDRnull mice as a result of VDR inactivation leading to an increase in production of Angiotensin II, which plays the central role in the occurrence of polyuria $[29,30]$ The underlying relationship of Aquaporins (AQP), also known as water channel proteins involved in controlling water transport and Vitamin D/VDR mediated urinary development, was investigated in another animal study on both knockout and wild type mice and found that $1 \alpha$ $(\mathrm{OH})$ ase knockout mouse developed polyuria, suggesting that vitamin D can control the urine production and excretion [31].

Another Iranian study revealed that supplementation with omega-3 and vitamin D may decrease the frequency of bed-wetting among children with NE. While there was still no specific mechanism for their operation to reduce bed-wetting in enuretic children, there was stronger evidence of improvement with vitamin $D$, researchers said [32]. 


\section{Limitations}

First, the sample size is small, so more prospective studies with larger series are needed to confirm our results. Also, there was no evaluation for sleep quality, habits, and sleep disorders, such as a structured comprehensive questionnaire or polysomnography, a gold standard method for sleep-disordered breathing. To understand the mechanisms of serum VD deficiency in NE patients, more studies should be conducted to focus on the effect of VD supplementation in children with $\mathrm{NE}$ and its impact on clinical symptoms, severity, and ameliorate the risk of NE.

\section{Conclusion}

There is a significant decrease in 25-Hydroxyvitamin D levels in children and adolescents with primary monosymptomatic nocturnal enuresis comparing to children without enuresis. This test can be used in regular investigations of enuretic children if vitamin D deficiency is found in larger series. As a result, the effectiveness of vitamin D supplementation may be evaluated in children with low levels.

\section{Abbreviation \\ NE: Nocturnal enuresis}

\section{Acknowledgements}

We thank the staff of Pediatric psychiatry Clinic in Ain-Shams University hospitals for their collaboration in sampling as well as the children who participated in the study.

\section{Authors' contributions \\ FM, RI, MG and AS contributed to the study conception and design. RI, MG and AS contributed to material preparation, data collection and analysis. RI wrote the first draft of the manuscript and all authors commented on previous versions of the manuscript. All authors read and approved the final manuscript.}

\section{Funding}

No funding was received for this research.

\section{Availability of data and materials}

The datasets used and/or analyzed during the current study are available from the corresponding author on reasonable request.

\section{Declarations}

\section{Ethics approval and consent to participate}

Participation in the study was voluntary, and written consent was obtained from the parents of all the children participating in the study and the approval from the Ain Shams University Ethics committee was obtained FMASU R86 /2020.

\section{Consent for publication}

Not applicable.

\section{Competing interest}

No competing interest is declared by any of the authors.

\section{Author details}

${ }^{1}$ Pediatrics Department, Faculty of Medicine, Ain Shams University, Cairo, Egypt. ${ }^{2}$ Egyptian Ministry of Health, Cairo, Egypt.

Received: 6 January 2021 Accepted: 28 July 2021

Published online: 01 September 2021

\section{References}

1. Austin PF, Bauer SB, Bower W, Chase J, Franco I, Hoebeke P et al (2016) (2016) The standardization of terminology of lower urinary tract function in children and adolescents: update report from the standardization Committee of the International Children's continence society. Neurourol Urodyn 35(4):471-481. https://doi.org/10.1002/nau.22751

2. Neveus T, Eggert P, Evans J et al (2010) Evaluation of and treatment for monosymptomatic enuresis: a standardization document from the International Children's Continence Society. J Urol 183:441. https://doi.org/10. 1016/j.juro.2009.10.043

3. Hadinezhad Makrani A, Moosazadeh M, Nasehi M, Abedi G, Afshari M, Farshidi F et al (2015) Prevalence of enuresis and its related factors among children in Iran: a systematic review and meta-analysis. Int J Pediatr 3(61):995-1004. https://doi.org/10.22038/ijp.2015.5142

4. Mohammed AH, Saleh AG, Al ZI (2014) Frequency of bedwetting among primary school children in Benha city, Egypt. Egypt J Med Hum Genet 15:287-292. https://doi.org/10.1016/j.ejmhg.2014.01.005

5. Kamal NN, Mahrous MD (2019) The epidemiology and factors associated with nocturnal enuresis among primary school children in Minia City, Egypt. EJCM 37:63-71. https://doi.org/10.21608/ejcm.2019.28133

6. Neveus T (2017) Pathogenesis of enuresis: towards a new understanding. Int J Urol 24(3):174-182. https://doi.org/10.1111/iju.13310

7. Khammissa RAG, Fourie J, Motswaledi MH, Ballyram R, Lemmer J, Feller $\mathrm{L}$ (2018) The biological activities of vitamin D and its receptor in relation to calcium and bone homeostasis, cancer, immune and cardiovascular systems, skin biology, and oral health. Biomed Res Int 22:9276380. https:// doi.org/10.1155/2018/9276380

8. Ahmed SZ, Jaleel A, Hameed K, Qazi S, Suleman A (2015) Does vitamin D deficiency contribute to the severity of asthma in children and adults? J Ayub Med Coll Abbottabad 27(2):458-463

9. Li L, Zhou H, Yang X et al (2014) Relationships between 25-hydroxyvitamin $D$ and nocturnal enuresis in five to seven year old children. PLOS ONE 9(6):e99316. https://doi.org/10.1371/journal.pone.0099316

10. Fahmy SI, Nofal LM, Shehata SF, El Kady HM, Ibrahim HK (2015) Updating indicators for scaling the socioeconomic level of families for health research. J Egypt Public Health Assoc 90(1):1-7. https://doi.org/10.1097/ 01.EPX.0000461924.05829.93

11. Holick MF, Binkley NC, Bischoff-Ferrari HA, Gordon CM, Hanley DA et al (2011) Evaluation, treatment, and prevention of vitamin D deficiency: an Endocrine Society clinical practice guideline. J Clin Endocrinol Metab 96:1911-1930. https://doi.org/10.1210/jc.2011-0385

12. Huang HM, Wei J, Sharma S, Bao Y, Li F, Song JW, Wu HB et al (2020) Prevalence and risk factors of nocturnal enuresis among children ages 5-12 years in Xi'an, China: a cross-sectional study. BMC Pediatr 20(1):305. https://doi.org/10.1186/s12887-020-02202-w

13. Alhifthy EH, Habib L, Abu Al-Makarem A, AlGhamdi M, Alsultan D et al (2020) Prevalence of nocturnal enuresis among Saudi children population. Cureus. 2(1):e6662. https://doi.org/10.7759/cureus.6662

14. Hamed A, Yousf F, Hussein MM (2017) Prevalence of nocturnal enuresis and related risk factors in school-age children in Egypt: an epidemiological study. World J Urol 35(3):459-465. https://doi.org/10.1007/ s00345-016-1879-2

15. Gunes A, Gunes G, Acik Y, Akilli A (2009) The epidemiology and factors associated with nocturnal enuresis among boarding and daytime school children in Southeast of Turkey: a cross sectional study. BMC Public Health. https://doi.org/10.1186/1471-2458-9-357

16. Dolgun G, Savaser S, Balci S, Yazici S (2012) Prevalence of nocturnal enuresis and related factors in children aged 5-13 in istanbul. Iran J Pediatr 22(2):205

17. Bilal M, Haseeb A, Saeed A, Saeed A, Sarwar T, Ahmed S, Ishaque A, Raza M (2020) Prevalence of nocturnal enuresis among children dwelling in 
rural areas of Sindh. Cureus 12(8):e9590. https://doi.org/10.7759/cureus. 9590

18. Albayrak S, Zengin K, Tanik S, Daar G, Ozdamar MY et al (2014) Vitamin B12, folate and iron levels in primary nocturnal enuresis. Pak J Med Sci 31:87-90. https://doi.org/10.12669/pjms.311.6424

19. Altunoluk B, Davutoglu M, Garipardic M, Bakan V (2012) Decreased vitamin B12 levels in children with nocturnal enuresis. ISRN Urol. https://doi. org/10.5402/2012/789706

20. Dhondt K, Baert E, Van Herzeele C, Raes A, Groen LA, Hoebeke P et al (2014) Sleep fragmentation and increased periodic limb movements are more common in children with nocturnal enuresis. Acta Paediatr 103(6):e268e72. https://doi.org/10.1111/apa.12610

21. Gu Y-M, Kwon JE, Lee G, Lee SJ, Suh HR, Min S, Cho MH (2016) Sleep problems and daytime sleepiness in children with nocturnal enuresis. Childhood Kidney Dis 20(2):50-56. https://doi.org/10.3339/jkspn.2016. 20.2.50

22. Neveus T (2008) Enuretic sleep: deep, disturbed or just wet? Pediatr Nephrol 23:1201-1202. https://doi.org/10.1007/s00467-008-0859-1

23. Eyles DW, Liu PY, Josh P, Cui X (2014) Intracellular distribution of the vitamin $d$ receptor in the brain: comparison with classic target tissues and redistribution with development. Neuroscience 268:1. https://doi.org/10. 1016/j.neuroscience.2014.02.042

24. Stumpf WE, O'Brien LP (1987) 1, 25(OH) 2 vitamin D 3 sites of action in the brain. Histochemistry 87:393-406. https://doi.org/10.1007/bf00496810

25. Massa J, Stone KL, Wei EK, Harrison SL, Barrett-Connor E et al (2015) Vitamin D and actigraphic sleep outcomes in older community-dwelling men: the MROS sleep study. Sleep 38:251-257. https://doi.org/10.5665/ sleep. 4408

26. Jablonski KL, Chonchol M, Pierce GL, Walker AE, Seals DR (2011)

25-hydroxyvitamin d deficiency is associated with inflammation-linked vascular endothelial dysfunction in middle-aged and older adults. Hypertension 57:63. https://doi.org/10.1161/HYPERTENSIONAHA.110.160929

27. Martens PJ, Gysemans C, Verstuyf A, Mathieu AC (2020) Vitamin D's effect on immune function. Nutrients 12(5):1248. https://doi.org/10.3390/nu120 51248

28. McCarty DE, Reddy A, Keigley Q, Kim PY, Marino AA (2012) Vitamin D, race, and excessive daytime sleepiness. J Clin Sleep Med 8:693-697. https:// doi.org/10.5664/jcsm.2266

29. LiYC, Kong J, Wei M, Chen ZF, Liu SQ, Cao LP (2002) 1,25-Dihydroxyvi$\operatorname{tamin} D(3)$ is a negative endocrine regulator of the renin-angiotensin system. J Clin Invest 110:229-238. https://doi.org/10.1172/JCl15219

30. Kong J, Li YC (2003) Effect of angiotensin II type I receptor antagonist and angiotensin-converting enzyme inhibitor on vitamin $D$ receptor null mice. Am J Physiol Regul Integr Comp Physiol 285(1):R255-R261. https:// doi.org/10.1152/ajpregu.00517.2002

31. Fu Y, Zhu J, Zhang Y, Liu Z, Su H, Kong J (2019) Vitamin D regulates the expressions of AQP-1 and AQP-4 in mice kidneys. Biomed Res Int 27:3027036. https://doi.org/10.1155/2019/3027036

32. Rahmani E, Eftekhari MH, Fallahzadeh MH, Fararouei M, Massoumi SJ (2018) Effect of vitamin D and omega-3 on nocturnal enuresis of 7-15-year-old children. J Pediatr Urol 14(3):257-257. https://doi.org/10. 1016/j.jpurol.2018.01.007

\section{Publisher's Note}

Springer Nature remains neutral with regard to jurisdictional claims in published maps and institutional affiliations.

\section{Submit your manuscript to a SpringerOpen ${ }^{\circ}$ journal and benefit from:}

- Convenient online submission

- Rigorous peer review

- Open access: articles freely available online

- High visibility within the field

- Retaining the copyright to your article

Submit your next manuscript at $\boldsymbol{\nabla}$ springeropen.com 